\title{
Toward Outcome Based Education (OBE): An Impact of Active Learning Approach for 'Computer Organization' Course
}

\author{
Snehal S. Patil ${ }^{1}$, Sushma S. Kulkarni ${ }^{2}$, Sachin K. Patil ${ }^{3}$ \\ ${ }^{1}$ Assistant Professor, Rajarambapu Institute of Technology, Sakharale, 415408, India. \\ ${ }^{2}$ Director, Rajarambapu Institute of Technology, Sakharale, 415408, India \\ ${ }^{3}$ Associate Professor, Rajarambapu Institute of Technology, Sakharale, 415408, India. \\ 'archana.jakhale@ritindia.edu \\ 2director@ritindia.edu \\ ssachink.patil@ritindia.edu
}

\begin{abstract}
In recent years, there is an incredible development in technology, which brought innovative changes in the educational sector. Active learning approaches are vital in teaching learning process such as content delivery, assessment, monitoring, etc. This paper discussed about active learning activities as simulation tool, buzz activity through animated video, and poster presentation. In addition to this, we checked students' performance and impact to gain knowledge by considering result analysis and course outcome attainment of two consecutive years for "computer organization" course. Individual students learning performance and learning interest increased due to implementation of different active learning tools during classes.
\end{abstract}

Keywords: Outcome Based Education (OBE), Buzz Activity, Computer Organization, Poster Presentation, Simulation Tool.

\section{Introduction:}

Emphasis on OBE in the current era enhances the education quality (Bonwell and Eison, 1991; Doyle,2008; Ugale and Shingan,2018). OBE is a student centered learning approach. Student's involvement while learning is an important part in OBE. Active learning tools have a vital role in student

\section{Snehal S. Patil}

Assistant Professor,

Rajarambapu Institute of Technology, Sakharale, 415408, India. archana.jakhale@ritindia.edu involvement in classrooms (Jakhale and Attar, 2015; Lokare et al. 2018). The course "Computer Organization" is a fundamental course in computer science and engineering stream. It contains basics of architecture of computer and arithmetic operation at machine level. In addition, this course has high weightage in GATE competitive exam and understanding this course content is a prerequisite for many courses like "Operation System", "System Programming" etc. Students find difficulty to understand such a course. Therefore, use of active learning tools help students in deep understanding of the course.

In this paper, we share our classroom experiences and present different active learning tools used for computer organization course for students involvement in the classroom. Also, we have checked the performance of students by comparing course result and course outcome attainment for two consecutive years.

Section 2 focuses on literature review of different active learning tools used for teaching learning process. Section 3 emphases on methodologies used to understand the systemic way to conduct different activities for computer organization course. Section 4 presents the effect of activity-based learning on students to retain knowledge. In the 5th section, we also compared the students performance in ISE-I and ISE- II tests conducted in the academic year 2019-20 and attainment of course to show impact of activities on students. Finally, section 6 offers concluding remarks of the activity. 


\section{Literature Review:}

Computer organization course is an essential part of the computer science stream (HalaElAarag,2012). Teaching such a course is difficult; students having trouble to understand concepts by traditional teaching (Xuejun Liang, 2008). Therefore, there should be use of active learning tools that will positively help students to understand the courses and to engage in their learning interest.

The National Survey of Student Engagement (NSSE, 2003) says that student engagement is not one of the single course of a student's academic career, but it's a pattern of his or her involvement in a variety of activities to understand concepts. His principle speaks directly that student engagement, is good practice with active learning tools like use of simulation tools, animated videos, gaming and poster presentation.

There are several lists of processor simulators available on the Internet (Binkert et al.,2011; Djordjevic et al.,2005; Magnusson et al.,2002; Mulia et al., 2013; Nikolic et al.,2009; Skrien et al,2001; Vollmar et al.,2006 ). There are many cache simulators to allow students to play with cache memory and memory hierarchy. The usage of visual simulators can improve both the teaching and learning processes. EDU-Cache simulator enable a visual environment to explain the basic cache memory concepts (Sasko et al, 2013). Educational games have made learners more motivated and interested learning (Ahmed et al.,2015).A poster presentation is a way to communicate research or understanding of a topic in a short and concise format (Aung and wi,2019). Gaming and poster presentation allow learners to learn this subject in a fun and interesting way. Therefore, this will be an encouraging student-faculty interaction, cooperation among students (Smith et al., 2005). It also increase the student's willingness and ability to learn the material.

Instead of traditional delivery in classroom like prompt lecture delivery, syllabus completion and preparing students for examinations; OBE focuses on enhancing learners' abilities, multi-intelligence, lifelong learning and ultimately meeting the expectations of the workplace (Aziz et al, 2005; Srimathi H, Krishnamoorthy A,2019).

\section{Methodology}

3.1 Active Learning Approach:
The concepts related to computer organization course are taught mainly by using different active learning approaches.

Learning Objectives for use of Active Learning Tools:

- Engage: To engage students by capturing their interest.

- Explore: To give opportunity to students in exploring their Skills.

- Explain/ Elaborate: Allow to explain concept, explanation follows experience.

- Evaluate: Review and reflect their learning to develop new understanding/skills.

\subsection{Classroom Implementation:}

During this study, tools like buzz activity and simulation were used in second year class(2017-18 batch) of computer science and engineering department of Rajarambapu Institute of Technology, Sakharale. This implementation was done for "Computer Organization" course. Total 79 students were selected/participated for/in the activity. Out of which 44 were girls and remaining were boys. We have formed groups of 3-4 students and conducted activity in each group. Activity is conducted throughout the semester.

Activity 1: Buzz Activity: It is a collaborative technique. In this activity faculty role is equally important as role of the students. Overview of buzz activity is described in Fig1.

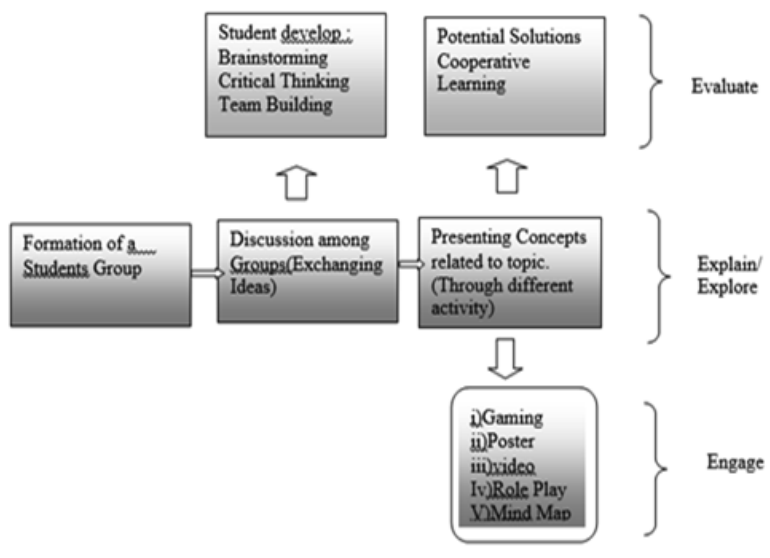

Fig. 1: Overview of Buzz Activity 


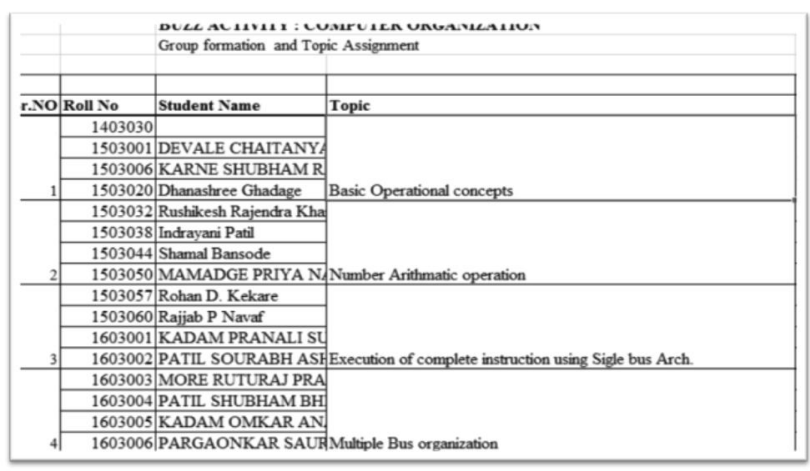

Fig 2:Group Formation and Assignment of Topic

\section{Procedure:}

1) Group Formation: Buzz groups are teams of three to four students that are formed to respond to course-related concepts (Topic). Fig 2 shows group formation and Topic assignment to students.

2) Discussion within the Group: Each group can discuss informally and exchange ideas. This discussion is effective for generating information and ideas in the given span of time.

3) Discussion with Faculty: The course teacher of computer organization is responsible to check their ideas and to give suggestions for the conduction of the activity.

4) Presentation: Students need to present their work/ideas in front of a classroom (through activities like Poster Presentation, Animated Videos, Gaming, etc.). Students can choose these activities as per their interest to demonstrate the concepts.

4.1 Poster Presentation: A poster presentation is a way to communicate your understanding of a topic in a short and concise form. It usually includes two elements - a poster and a brief (usually not more than 2 minutes) explanation. Students need to analyse and evaluate information, synthesize ideas and creatively demonstrate their understanding of the topic. Students can seek help from the faculty regarding it. Poster presentations develop their ability to communicate perceptively.

4.2 Animation Tools: It can be a valuable resource in the classroom. Students will demonstrate their understanding of concepts while they are creating the animations and the finished product can be uploaded to an online learning space. It will give them clear understanding of concepts.
4.3 Gaming: To deliver the concept games isused. For example Collecting information: In the game, the learner can use his/her game character to collect different items (like coins, key, etc.). Each one of these items gives the learner information regarding the computer architecture subject.

5) Comment and summarization: Faculty summarizes the concept and gives feedback.

6) Evaluation is done by faculty. The parameters (rubrics) are considered for evalutions are "Content and Explanation", "Depth of Knowledge" and "Delivery" (Fig 3).

\section{Rubrics for Buzz Activity Evaluation}

Course Detaik:
CLASS: Second Year, B. Tech
SEMESTER:IV YEAR: $2017-18$
COURSE TITLE: Computer Organization COURSE CODE: (CS2041)
PROGRAM/DEPT.: Computer Science and Engineering FACULTY: Mrs.S.SPatil

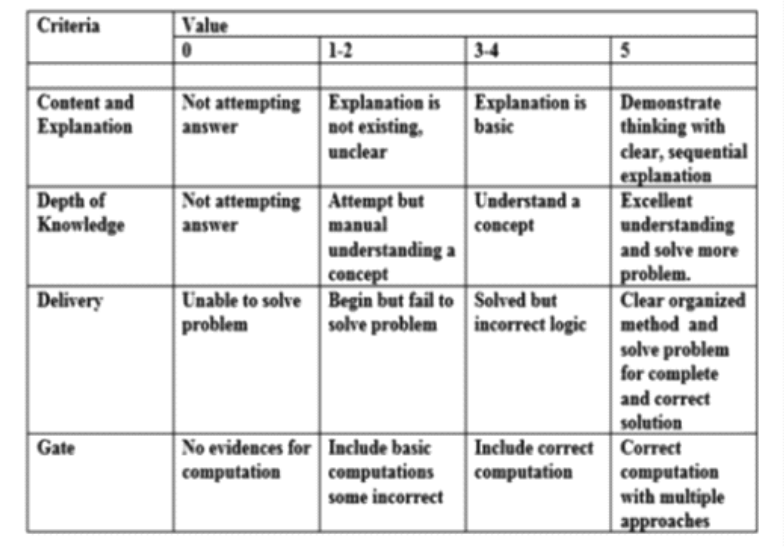

Fig. 3: Rubrics for Buzz Activity Evaluation.

Fig 4. highlights example of conduction of buzz activity. Group no.18 implemented buzz activity using poster presentation. The group has used poster presentation to explain hierarchy of memory concept. After students' presentations question/answer session was conducted. At the last faculty summarised the topic. In such an activity, students involvement is more than traditional teaching.

\section{Activity 2:}

Simulation Tool: A common use of simulation is for experimentation in a low-cost, low-risk environment. Through simulation tool, theoretical concepts are connected with actual implementation.Learning of the students is done by 


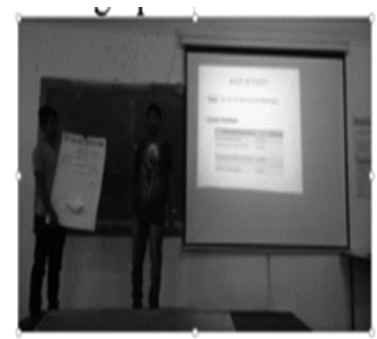

Question /Answer after presentation (Interaction between different group, reflecting on particular concept)

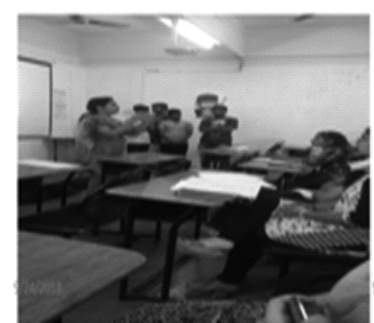

\section{Group No: 10}

Date. 12032018

C) Topic: Hiefarchy of Memory

Activity: Poster Presentation

(Engaging and enjoying classroom envitoement)

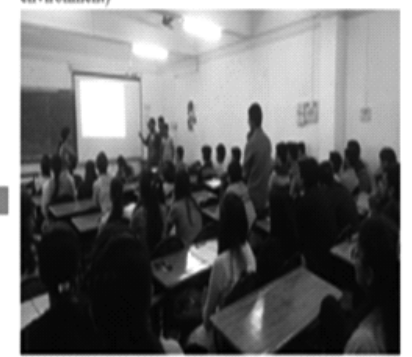

Summarization by faculty after

presetting coacepts.

(Macch Student aad faculty Expectation)

Fig. 4 : Poster Presentation for Buzz activity

experiencing it on their own. Some concepts like arithmetic operation at machine level, Booths algorithm, etc. are taught by using the Isrelkoren simulation tool. (Fig 5)

\section{Procedure:}

1) Installation of Tool

2) Experiencing tool with the help of manual.

\section{Findings/Outcomes of Overall Activities}

By using above mentioned active learning techniques, it is found that, both students and faculty are getting benefited.

Confidence level of students goes high. Student generates a large number of ideas for potential solutions. They develop team building and cooperative learning skills among them. Also, they become able to summarize, apply or integrate new information. They engage in their own learning activities.Deep understanding of the core concepts in the course is possible with such an activity. Students can apply the basic knowledge of architecture of computer in different applications. Also, they can practice on multiple-choice questions for competitive exams.

\section{(http://www.ecs.umass.edu/ece/koren/arith/simulator)}

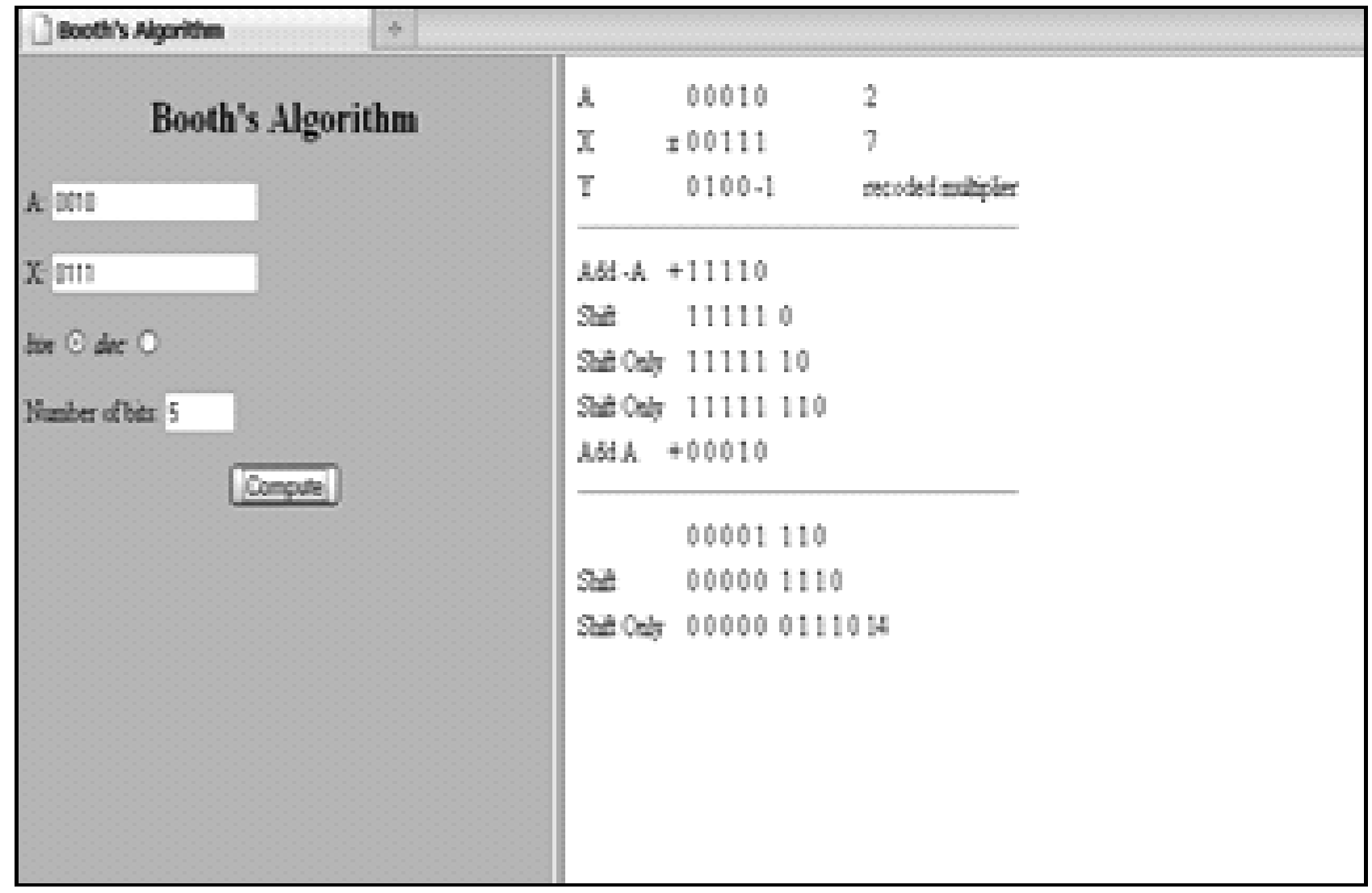

Fig. 5: Simulator used for "Booth's Algorithm" concept 
Implementation of activities create a positive teaching environment with well-organized lectures. Direct interaction between faculty and students, which hardly do in normal lectures. Therefore, it motivate both sides faculty and students with joyful teaching learning.

Some hurdles like class control, time consumption and assurance of all student involvement are found while implementation of activities.

Informal Feedback from the students using yellow paper concept (Fig.6) has been taken. Students have given positive feedback about active learning techniques.
Major points in the feedback activity from students:

- Increased depth of a particular topic.

- GATE questions get solved.

- Thinking ability is increased.

- In case of Poster presentation, preparation of poster requires time. Here some other technique can be used.

- Visualization gives better understanding of concepts.

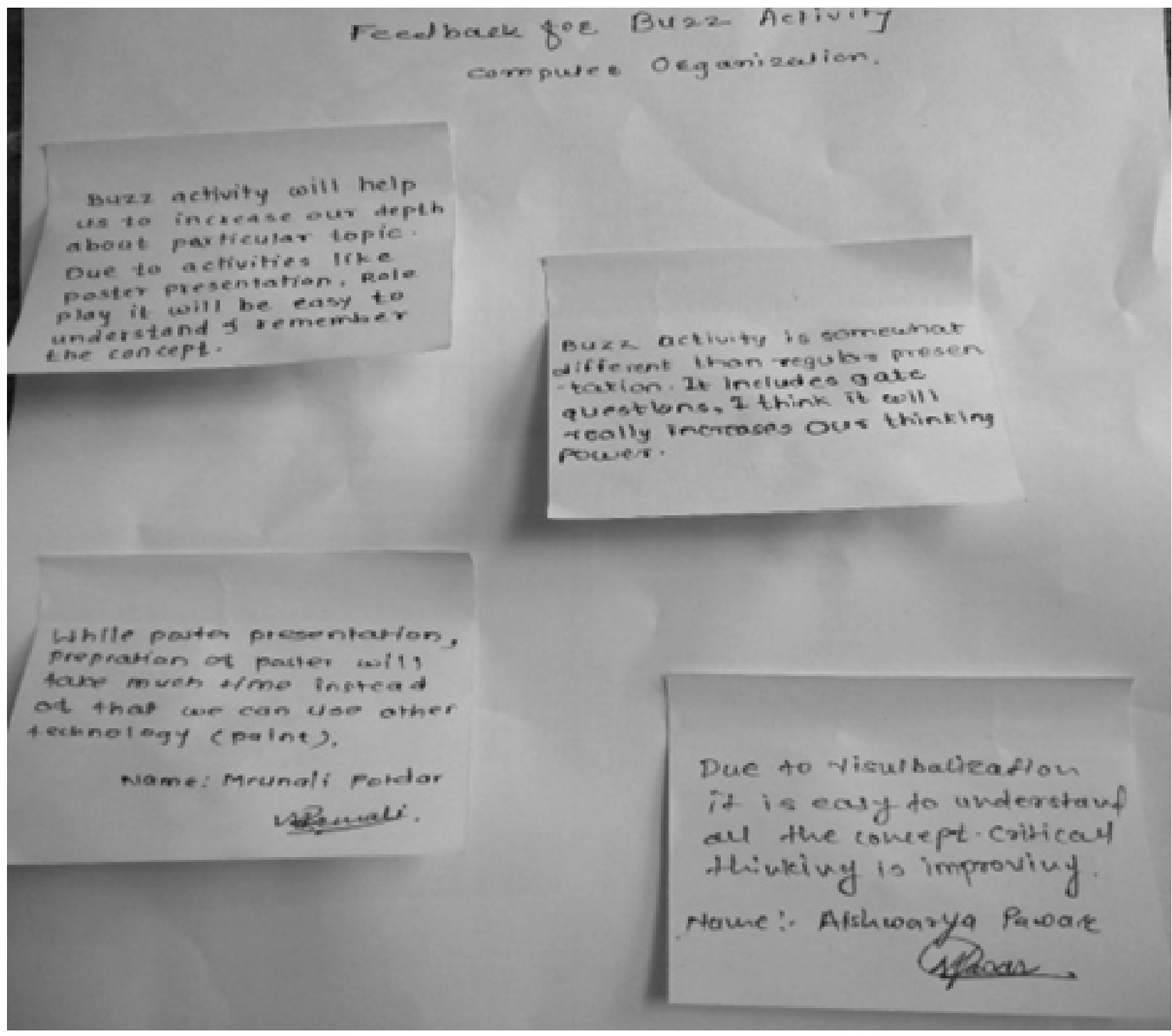

Fig. 6: Feedback for activity(Yellow Paper concept) 


\section{Result and Discussion}

The course, Computer Organization is difficult for the students. All these activities work efficiently and effectively on the course. The main goal to conduct this activity is students' better understanding of the concepts of the course. The activities are tested on 79 students of Second Year B. Tech Computer Science and Engineering.

We have analysed the activity by considering two ways

i) Comparison of Internal Semester Exam (ISE-I) marks (before conduction of activity) and ISE-II marks (after conduction of activity)

ii) $\mathrm{CO}$ Attainment of the Computer Organization course for two consecutive batches.

Initially, we have conducted ISE-I (before conduction of activity). It has been observed that students get lower grades. Further, we have analyzed $\operatorname{sco}$

Table1:Passing Percentage and Average Marks in UT-II is improved than UT-I

\begin{tabular}{|c|c|c|}
\hline & $\begin{array}{l}\text { ISE-I(before } \\
\text { Activity) }\end{array}$ & $\begin{array}{l}\text { ISE-II (After } \\
\text { Activity) }\end{array}$ \\
\hline Passing Percentage & $75.90 \%$ & $82 \%$ \\
\hline Avg Marks(out of 25) & 13 & 14.7 \\
\hline
\end{tabular}

Table2:Questions attempted

(on concepts covered in the activity)is increased

\begin{tabular}{|l|l|l|l|}
\hline Total Students & $\begin{array}{l}\text { No. of } \\
\text { Questions } \\
\text { related to } \\
\text { activity in } \\
\text { ISE-II }\end{array}$ & $\begin{array}{l}\text { No of Students } \\
\text { attempted } \\
\text { Questions on } \\
\text { Activity (out } \\
\text { of 79) }\end{array}$ & $\begin{array}{l}\text { Avg } \\
\text { Marks(out of } \\
\text { 12) }\end{array}$ \\
\hline 79 & 2 & 73 & 8.6 \\
\hline
\end{tabular}

res in ISE-I and ISE-II (after conduction of activity). The average score in ISE-I is 13 out of 25. However, in ISE-II, It has been increased to 15.5 out of 25 (Table). In addition to this, no of questions attempted by students related to activity in ISE-II is more. (Table)

Each program defines a program outcomes (POs) which are accessed, and evaluated at the end of four years of graduation. These attributes are acquired through course outcome (CO's) defined at every course and evaluated at every semester. Based on how well these two parts are defined and evaluated, OBE attainment is measured. Every internal assessment is considered for attainment. Hence, the attainment of CO's is the focus of teaching learning. With the active learning teaching process attainment of CO's is increased. Table 3. Shows course outcomes for "computer organization "Course with active learning tools used for respective CO's. It also contains points covered through activity with their outcome. As active learning tools have been adopted for batch of the year, 2017-18, significant impact in attainment is observed. From the graph (Fig.7) we analyze that attainment is increased for the batch 2017-18. So, active learning tools play an important role in increasing attainment. Table 4. Shows overall result analysis of computer organization course for two consecutive years. Fig. 8 shows a graph which indicates noticeable impact in the year 2018 by using active learning tools and improvement in grade of students as well.

\section{Conclusion}

Student engagement in learning is a very challenging task. As active learning tools like buzz activity through poster presentation, gaming, animated videos and simulation tools are applied to

Table 3 : Course Outcome with Attainment for computer Organization Course

\begin{tabular}{|c|c|c|c|c|c|}
\hline \multirow{2}{*}{ Course Outcome } & \multirow[t]{2}{*}{ Activity used } & \multirow{2}{*}{$\begin{array}{l}\text { The Points } \\
\text { covered } \\
\text { through } \\
\text { activity }\end{array}$} & \multirow[t]{2}{*}{ Outcomes } & \multicolumn{2}{|c|}{ Attainment } \\
\hline & & & & $\begin{array}{l}\text { Year } \\
2016- \\
17 \\
\end{array}$ & $\begin{array}{l}\text { Year } \\
2017- \\
18\end{array}$ \\
\hline $\begin{array}{l}\text { To conceptualize basics of organizational and } \\
\text { architectural issue, functional unit of processor in } \\
\text { digital computer and apply in computer organization }\end{array}$ & $\begin{array}{l}\text { Animated } \\
\text { Video }\end{array}$ & $\begin{array}{l}\text { Basic } \\
\text { Architecture } \\
\text { of Computer }\end{array}$ & $\begin{array}{l}\text {-Visualization through } \\
\text { animation, remember } \\
\text { concept for a long time }\end{array}$ & 46 & 66 \\
\hline $\begin{array}{l}\text { Construct the ability to perform computer arithmetic } \\
\text { operations such as binary, signed, decimal, } \\
\text { hexadecimal, floating point numbers. }\end{array}$ & $\begin{array}{l}\text { Simulation } \\
\text { Tool }\end{array}$ & $\begin{array}{l}\text { Arithmetic } \\
\text { Operations }\end{array}$ & $\begin{array}{l}\text { Theoretical concepts } \\
\text { connect with actual } \\
\text { implementation } \\
\text {-Students learning by } \\
\text { experiencing how to use } \\
\text { a simulator model. }\end{array}$ & 48 & 65 \\
\hline
\end{tabular}




\begin{tabular}{|l|l|l|l|l|}
\hline $\begin{array}{l}\text { Interpreting memory organization that uses banks for } \\
\text { different word size operations and cache mapping } \\
\text { techniques including translation, allocation. }\end{array}$ & $\begin{array}{l}\text { Buzz Activity: } \\
\text { Gaming, Poster } \\
\text { Presentation }\end{array}$ & $\begin{array}{l}\text { Memory } \\
\text { Management }\end{array}$ & $\begin{array}{l}\text {-Engage their own } \\
\text { learning }\end{array}$ & 54 \\
\hline $\begin{array}{l}\text { Ability to understand the input/output organization, } \\
\text { data transfer techniques for computer. }\end{array}$ & $\begin{array}{l}\text { Buzz Activity: } \\
\text { Animated } \\
\text { Video, }\end{array}$ & $\begin{array}{l}\text { Data Transfer } \\
\text { Techniques }\end{array}$ & $\begin{array}{l}\text {-Visualization through } \\
\text { animation, remember } \\
\text { concept for a long time }\end{array}$ & 42 \\
\hline $\begin{array}{l}\text { To analyz processor performance improvement -using } \\
\text { instruction level parallelism in digital a computer. }\end{array}$ & $\begin{array}{l}\text { Buzz Activity: } \\
\text { Video, Gaming }\end{array}$ & Parallelism & $\begin{array}{l}\text {-Engage their own } \\
\text { learning }\end{array}$ & 43 \\
\hline
\end{tabular}

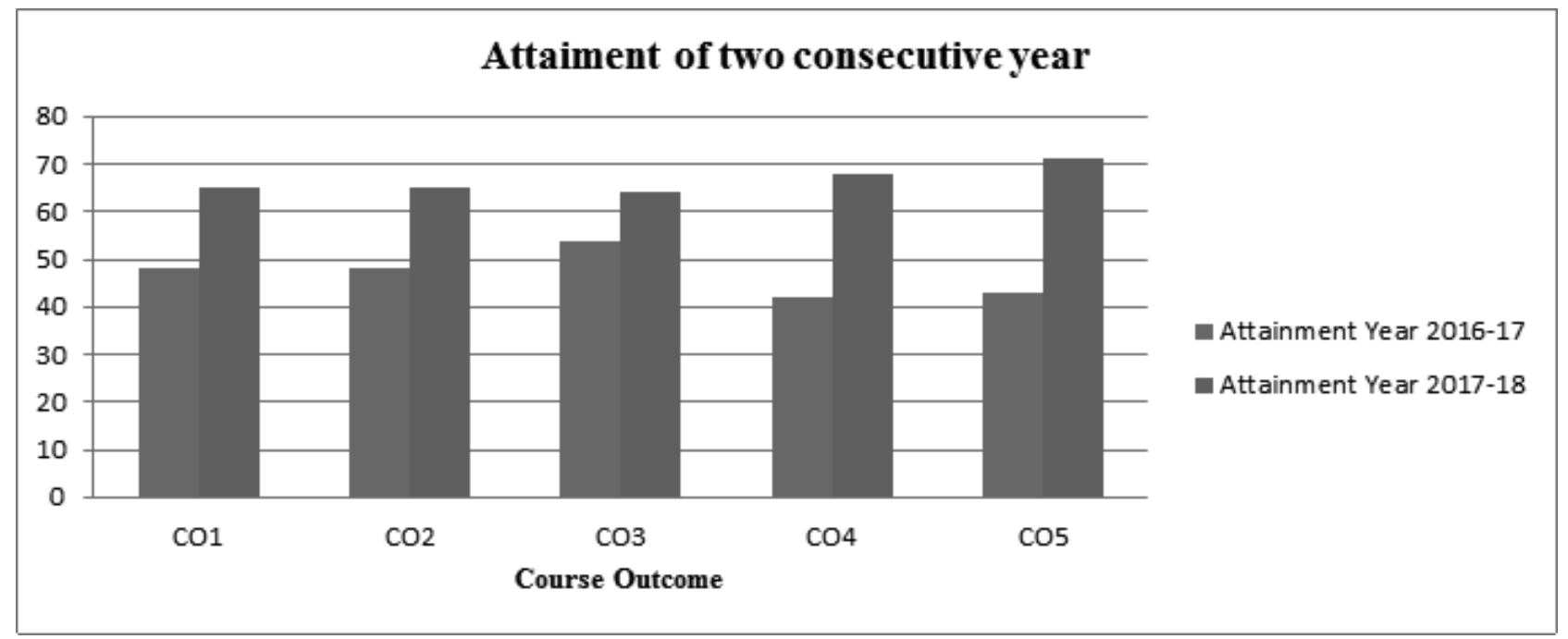

Fig 7:Attainment of two consecutive Years

Table 2. Result Analysis for Computer Organization Course

\begin{tabular}{|c|c|c|c|c|c|c|c|c|}
\hline \multirow[t]{2}{*}{ Year } & \multirow[t]{2}{*}{ Passing \% } & \multicolumn{7}{|c|}{ Grade and Range of Marks } \\
\hline & & $\begin{array}{l}\mathbf{A A} \\
(91-100\end{array}$ & $\begin{array}{l}\mathrm{AB} \\
(81-90)\end{array}$ & $\begin{array}{l}\text { BB } \\
(71-80)\end{array}$ & $\begin{array}{l}\mathrm{BC} \\
(61-70)\end{array}$ & $\begin{array}{l}\mathrm{CC} \\
(51-60)\end{array}$ & $\begin{array}{l}\text { CD } \\
(41-50)\end{array}$ & $\begin{array}{l}\text { DD } \\
(31-40)\end{array}$ \\
\hline 2017 & 92.20 & - & 1 & 8 & 14 & 31 & 14 & 1 \\
\hline 2018 & 97.29 & - & 5 & 23 & 23 & 9 & 10 & 1 \\
\hline
\end{tabular}

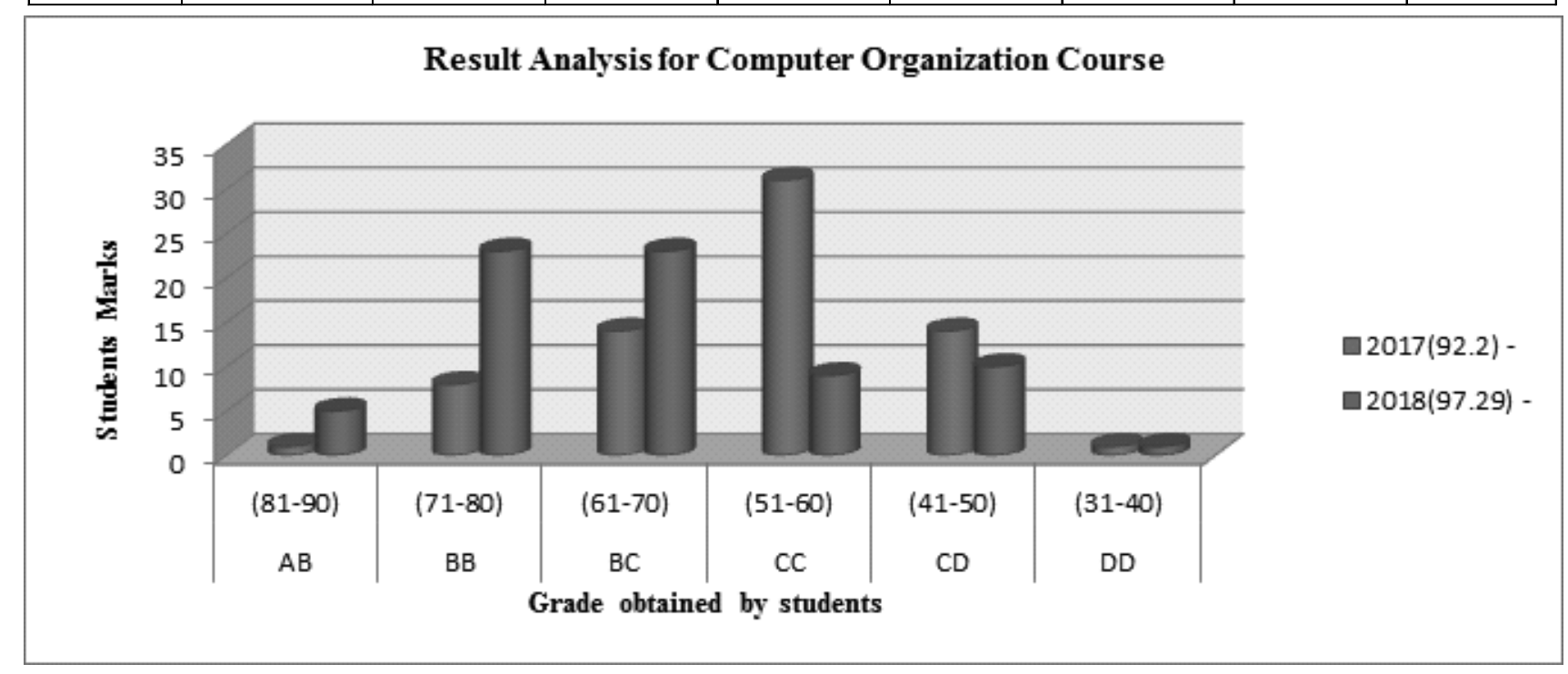

Fig 8:Result Analysis for Computer Organization Course 
computer organization it creates a significant impact on overall performance of the students. The feedback revealed common agreement that "activity based learning" helped students to generate interest, better understanding \& promotes self-directed subject learning.

\section{References}

[1] Zhao, J., Pablo, P. and Qi, Z. (2012) Enterprise knowledge management model based on China's practice and case study, Computers in Human Behavior, 28(2), 324-330.

[2] Bonwell, C., Eison, J. (1991) Active learning: Creating excitement in the classroom (ASHEERIC Higher Education Report No. 1). Washington, DC: George Washington University. Abstract online at_http://www.ed.gov/databases/ ERIC_Digests/ed340272.html

[3] Doyle, T. (2008) Helping students learn in a learner-centered environment: A guide to facilitating learning in higher education. Sterling, VA: Stylus Publishing.

[4] Jakhale, A., Attar, A. (2015) A Novel Approach towards Outcome Based Engineering Education for Continuous Quality Improvement: A Case study, Journal of Engineering Education Transformations.

[5] Lokare, V., Jadhav, P., Patil, S. (2018) An integrated approach for teaching object oriented programming $(\mathrm{c}++)$ Course, Journal of Engineering Education Transformations, 31(3), $17-23$.

[6] Ugale, B., Shingan, G. (2018) A novel approach to improve logical and critical thinking through collaborative learning and using visualization tools, Journal of Engineering Education Transformations.http://www.ecs.umass.edu/ece/ koren/arith/simulator/

[7] Smith, K., Sheppard, S., Johnson, W. and Johnson, T. (2005) Pedagogies of Engagement: Classroom-Based Practices. J. Eng. Educ. 94, 87101.

[8] Aziz, A. MegatMohd Noor, M. Abang Ali, A. and Jaafar, M. (2005) A Malaysian outcome-based engineering education model. International
Journal of Engineering and Technology 2(1), 14-21.

[9] HalaElAarag. (2012) Teaching computer organization: apractical approach, J. Comput. Sci. Coll, 28(2) 210-217.

[10]Xuejun, L., (2008) A Survey of Hands-on Assignments and Projects in Undergraduate Computer Architecture Courses Advances in Computer and Information Sciences and Engineering, ISBN : 978-1-4020-8740-0

[11]Sasko, R. Marjan, G. Blagoj, A. Nenad, A.(2013) Using EDUCache Simulator for the Computer Architecture and Organization Course, International Journal of Engineering pedagogy, $3(3)$.

[12]National Survey of Student Engagement: The College Student Report-2003 Annual Report, Bloomington, IN: Center for Postsecondary Research, Indiana University, 2003.

[13]Srimathi, H. Krishnamoorthy, A. (2019) Faculty Development on Active Learning ,International Journal of Recent Technology and Engineering (IJRTE) ISSN: 2277-3878,(8)1.

[14]Binkert, N., Beckmann, B., Black, G., Reinhardt, S. K.,Saidi, ., Basu, A., ... \& Sen, R. (2011) The gem5 simulator. ACM SIGARCH computer architecture news, 39(2), 1-7.

[15]Djordjevic, J., Nikolic, B., \& Milenkovic, A. (2005). Flexible web-based educational system for teaching computer architecture and organization. IEEE Transactions on Education, 48(2), 264-273.

[16]Magnusson, P. S., Christensson, M., Eskilson, J., Forsgren,

[17]D., Hallberg, G., Hogberg, J., ... \& Werner, B. (2002). simics: A full system simulation platform. Computer, 35(2), 50-58.

[17]Mulia, W. D., Fritz, D. J., Sohoni, S. A., Kearney, K., \& Mwavita, M. (2013). PLP: A Community Driven Open Source Platform for Computer Engineering Education.International Journal of Engineering Education, 29(1), 215-229. 
[18]Nikolic, B., Radivojevic, Z., Djordjevic, J., \& Milutinovic, V. (2009). A survey and evaluation of simulators suitable for teaching courses in computer architecture and organization. IEEE Transactions on Education, 52(4), 449-458.

[19]Skrien, D. (2001). CPU Sim 3.1: A tool for simulating computer architectures for computer organization classes. Journal on Educational Resources in Computing (JERIC), 1(4), 46-59.
[20]Vollmar, K., \& Sanderson, P. (2006, March). MARS: an education-oriented MIPS assembly language simulator. In Proceedings of the 37th SIGCSE technical symposium on Computer science education (pp. 239-243). 